Electronic abbreviations, symbols

and terms 


\section{THORN EMI HOME ELECTRONICS/MACMILLAN SERIES}

\section{Books}

Electronic abbreviations, symbols and terms VHS recording principles

An introduction to digital techniques books An introduction to digital techniques: logic gates, flip-flops, counters and shift registers

Digital displays and applications: decoders and encoders, memories, text data acquisition, viewdata An introduction to microprocessors: microprocessors, programs, interfacing, timesharing, data transfer

\section{Tutor boards}

Digital tutor board with exercise book

Transistor tutor board with exercise book

\section{Video tapes}

Introduction to microprocessor systems

Introduction to the teletext system

VHS mechanical principles

For the tutor

Two-day teletext course

Basic VHS course

\section{For everyone}

Basic mathematical skills 


\title{
Electronic abbreviations, symbols and terms
}

\author{
SECOND EDITION
}

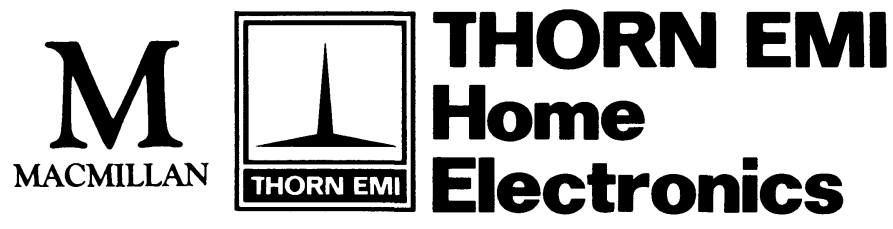


( THORN EMI Television Rentals Ltd 1984, 1985

All rights reserved. No reproduction, copy or transmission of this publication may be made without written permission.

No paragraph of this publication may be reproduced, copied or transmitted save with written permission or in accordance with the provisions of the Copyright Act 1956 (as amended).

Any person who does any unauthorised act in relation to this publication may be liable to criminal prosecution and civil claims for damages.

First published 1984

Published in this format in 1985 by MACMILLAN EDUCATION LTD

Houndmills, Basingstoke, Hampshire RG21 2XS and London

Companies and representatives

throughout the world

British Library Cataloguing in Publication Data

Electronic abbreviations, symbols and terms.-

(THORN EMI Home Electronics series)

1. Electronics-Abbreviations

I. Series

$621.381^{\prime} 0148$

TK7804

ISBN 978-0-333-39167-9

DOI 10.1007/978-1-349-07966-7

ISBN 978-1-349-07966-7 (eBook) 


\title{
CONTENTS
}

\author{
Introduction 7 \\ Abbreviations (alphabetical order) 2 \\ Symbols commonly used Greek letters 9 \\ mathematical 9 \\ CRTs 10 \\ capacitors 12 \\ coils, transformers 14 \\ fuses, resistors 16 \\ waveforms 19 \\ battery 21 \\ semiconductors 22 \\ miscellaneous 31 \\ filters 35 \\ logic 35 \\ data processing flowchart 39 \\ cable distribution systems 40 \\ Terms video recording 48 \\ microprocessing 57
}

Appendix component colour code system 67

Index 74 